\title{
Microstructures and Mechanical Properties of Tungsten Inert Gas Welded Magnesium Alloy AZ91D Joints
}

\author{
D. Q. SUN, D. X. SUN, S. Q. YIN and J. B. LI
}

Key Laboratory of Automobile Materials, School of Materials Science and Engineering, Jilin University at Nanling Campus, No. 142 Renmin Street, Changchun 130025, P. R. China. E-mail: sundexinaa@126.com

(Received on March 1, 2006; accepted on May 23, 2006)

\begin{abstract}
Effects of weld composition and heat input on microstructures and mechanical properties of tungsten inert gas (TIG) welded magnesium alloy AZ91D joints have been investigated. Increasing magnesium alloy weld $\mathrm{Al}$ contents from 6.9 to $9.8 \mathrm{wt} \%$, the area fraction of brittle $\mathrm{Al}_{12} \mathrm{Mg}_{17}$ phases in the weld metals increased from 6.2 to $7.3 \%$ and the strength and elongation of the weld metals decreased from $215 \mathrm{MPa}$ and $7.9 \%$ to $192 \mathrm{MPa}$ and $4.9 \%$. Increasing the heat inputs from 73.6 to $147.2 \mathrm{~kJ}$ resulted in the grain coarsening of the weld metals and the partially melted zone (PMZ) width increasing from 120 to $210 \mu \mathrm{m}$. The mechanical properties of welded joints are poor compared with those of the base metal AZ91D. The strength and elongation of the joints are about $70 \%$ and $73 \%$ of the strength $(156 \mathrm{MPa})$ and elongation $(4.8 \%)$ of the base metal, respectively. The joint fractures mainly occurred in the $\mathrm{PMZ}$ with broader $\mathrm{Al}_{12} \mathrm{Mg}_{17}$ phases at the grain boundaries.
\end{abstract}

KEY WORDS: magnesium alloys; TIG welding; microstructures; mechanical properties.

\section{Introduction}

The light weight, high specific strength, and recycleable characteristics of magnesium alloys have recently attracted great attention in academic research and industry applications. $^{1-3)}$ Especially within transportation industries, the weight saving effect of replacing steel and aluminium parts is an important factor in reducing fuel consumption and increasing speed. Besides the development of new alloy types, manufacturing techniques such as welding and joining play an important role in exploiting the new fields of applications.

There has been some research activity on welding of magnesium alloys in recent years. Various welding processes, principally laser welding, electron beam welding, tungsten inert gas welding, friction stir welding and transient liquid phase bonding, were employed in the investigations. ${ }^{4-8)}$ Although many useful insights and data have been obtained, there are still many issues to be addressed before welded magnesium alloy parts can be fully used in real industrial applications. Therefore, further research and development efforts related to welding of magnesium alloys are required to utilize the full potential of these materials. The tungsten inert gas (TIG) welding has proven itself to be an economically affordable and efficient method for the joining of magnesium alloys. However, up to now, the information on TIG welding of magnesium alloys is still limited, and microstructures and mechanical properties of TIG welded magnesium alloy joints have not been completely understood since the alloy compositions vary significantly. It has become one of main problems for welding of magne- sium alloys.

The purpose of this investigation is to reveal effects of weld composition and heat input on microstructures and mechanical properties of TIG welded magnesium alloy AZ91D joints and to obtain better understanding of the weldability of magnesium alloy AZ91D.

\section{Experimental Procedure}

In this investigation, magnesium alloy AZ91D test plates with dimensions of $120 \mathrm{~mm} \times 80 \mathrm{~mm} \times 10 \mathrm{~mm}$, and two kinds of magnesium alloy welding wires with a diameter of $3.0 \mathrm{~mm}$ were employed as the base metal and the filler metals, respectively. The compositions of the base metal and welding wires are listed in Table $\mathbf{1 .}$

Test holes of $13 \mathrm{~mm}$ in diameter and $6 \mathrm{~mm}$ in depth were machined on the test plates (Fig. 1). ${ }^{9)}$ Prior to welding the surface oxidation films of the test plates and the welding wires were removed and then weld metals with different compositions were deposited (not preheated) in the test holes by using TIG welding machine (PANA-TIG-WP300) with Ar shielding gas at different heat inputs $(Q=I V t)$. The welding current $(I)$, welding voltage $(V)$ and wire feeding speed were $160 \mathrm{~A}, 23 \mathrm{~V}$ and $400 \mathrm{~mm} / \mathrm{min}$ respectively, and the different heat inputs $(73.6 \mathrm{~kJ}, 110.4 \mathrm{~kJ}$ and $147.2 \mathrm{~kJ})$ were obtained by changing welding time $(t)$. After welding, the welded test plate cooled to room temperature in air. For microstructural examinations, welded joint specimens $(20 \mathrm{~mm} \times 10 \mathrm{~mm} \times 10 \mathrm{~mm})$ were cut down from welded test plates and were prepared by standard metallographic procedures. The microstructures of welded joints were examined 
Table 1. Chemical compositions of magnesium alloy base metal and welding wires.

\begin{tabular}{ccccccccc}
\hline Base metal and welding wire & $\mathrm{Al}$ & $\mathrm{Zn}$ & $\mathrm{Mn}$ & $\mathrm{Si}$ & $\mathrm{Fe}$ & $\mathrm{Cu}$ & $\mathrm{Ni}$ & $\mathrm{Mg}$ \\
\hline Base metal AZ91D & 9.4 & 0.62 & 0.24 & 0.015 & 0.005 & 0.014 & 0.001 & Bal. \\
Welding wire A & 9.4 & 0.62 & 0.24 & 0.015 & 0.005 & 0.014 & 0.001 & Bal. \\
Welding wire B & 6.4 & 0.17 & 0.57 & 0.013 & 0.005 & 0.017 & 0.001 & Bal. \\
\hline
\end{tabular}

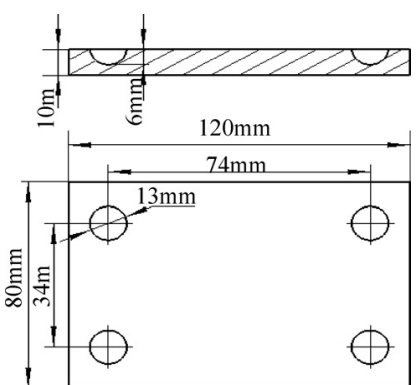

Fig. 1. Schematic drawing of test plates with test holes.

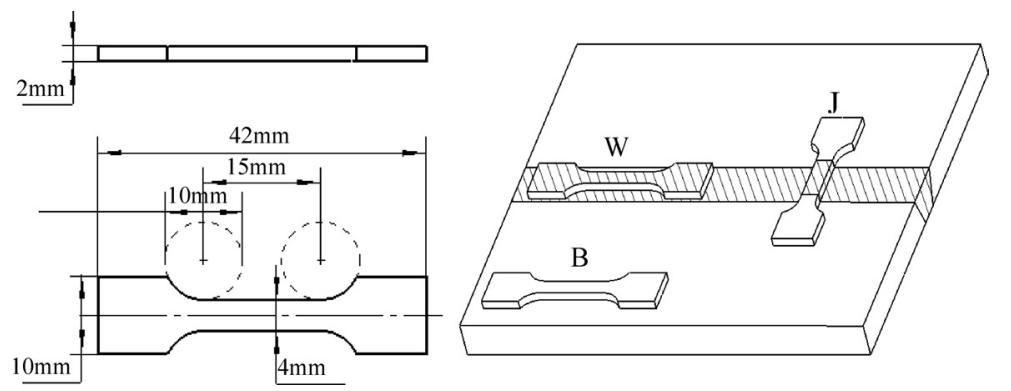

Fig. 2. Schematic drawing of three types of tensile test specimens. using optical and scanning electron microscopy (SEM) and $\mathrm{X}$-ray diffraction (XRD). The distribution of alloying elements was measured using energy dispersive X-ray spectroscopy (EDS) and by wet chemical analysis. The area fraction of $\mathrm{Al}_{12} \mathrm{Mg}_{17}$ phases in the weld metals and the width of partially melted zone were determined using an image analysis system.

For mechanical properties examinations, a longitudinal V-groove with $60^{\circ}$ angle and $8.4 \mathrm{~mm}$ depth was milled in the test plate $(120 \mathrm{~mm} \times 80 \mathrm{~mm} \times 10 \mathrm{~mm})$, and weld metals were deposited in the $\mathrm{V}$ groove, the welding current, welding voltage, welding speed and wire feeding speed being $160 \mathrm{~A}, 23 \mathrm{~V}, 350 \mathrm{~mm} / \mathrm{min}$ and $430 \mathrm{~mm} / \mathrm{min}$ respectively. The tensile specimens of base metal (B), weld metal (W) and welded joint $(\mathrm{J})$ were machined in the form of a gauge section $15 \mathrm{~mm}$ long and $4 \mathrm{~mm}$ wide, as illustrated in Fig. 2. The mechanical properties of the base metal, weld metal and welded joint were determined using tensile test machine (MT810 material testing systems), based on the average value over three measurements per condition.

\section{Results and Discussion}

\subsection{Microstructures of Joints}

TIG welded magnesium alloy AZ91D joints contain the fusion zone (FZ), heat affected zone (HAZ) and base metal zone (BMZ). Figure 3 illustrates a typical microstructure of base metal AZ91D. From XRD pattern shown in Fig. 4, it can be seen that the microstructure of the base metal consists of magnesium solid solution $(\alpha-\mathrm{Mg})$ and $\mathrm{Al}_{12} \mathrm{Mg}_{17}$ intermetallic compound $\left(\beta-\mathrm{Al}_{12} \mathrm{Mg}_{17}\right)$. The dark and light phases correspond, respectively, to $\alpha-\mathrm{Mg}$ and $\beta-\mathrm{Al}_{12} \mathrm{Mg}_{17}$, and the $\beta-\mathrm{Al}_{12} \mathrm{Mg}_{17}$ mainly distribute along $\alpha-\mathrm{Mg}$ grain boundaries.

The experimental results indicated that microstructures of the fusion zone (weld metal) mainly depend on the chemical composition and the heat input of welding. In this investigation, it was found that $\mathrm{Al}$ contents of weld metals were higher than those of the magnesium alloy welding wires used. Al contents in the weld metals obtained by welding wire $\mathrm{B}(6.4 \mathrm{wt} \% \mathrm{Al})$ and welding wire A $(9.4 \mathrm{wt} \%$ $\mathrm{Al}$ ) were $6.9 \mathrm{wt} \%$ and $9.8 \mathrm{wt} \%$ respectively, which is mainly

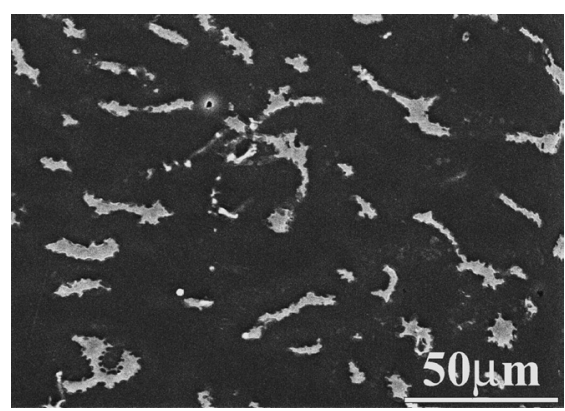

Fig. 3. Microstructure of base metal AZ91D.

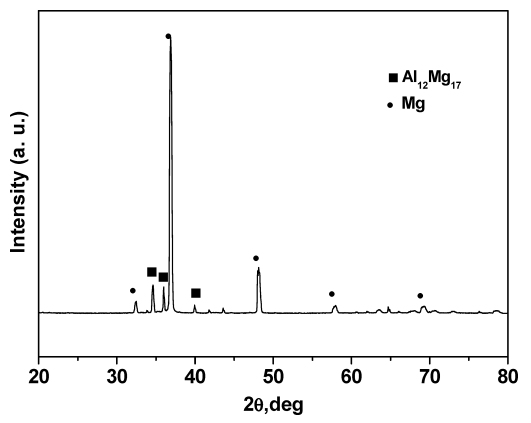

Fig. 4. X-ray diffraction pattern of base metal.

associated with $\mathrm{Mg}$ evaporation during TIG welding. Figure. 5 shows microstructures of the magnesium alloy weld metals with different $\mathrm{Al}$ contents. Compared with the base metal, the weld metals have a similar phase composition ( $\alpha$ - Mg and $\beta-\mathrm{Al}_{12} \mathrm{Mg}_{17}$ at grain boundaries) and a finer microstructure due to the relatively high cooling rate. The weld $\mathrm{Al}$ contents have the effect on the area fraction of $\beta$ $\mathrm{Al}_{12} \mathrm{Mg}_{17}$ in the weld metals. Increasing weld $\mathrm{Al}$ contents from 6.9 to $9.8 \mathrm{wt} \%$, the area fraction of $\beta-\mathrm{Al}_{12} \mathrm{Mg}_{17}$ increased from 6.2 to $7.3 \%$. Further investigation found that there exists a secondary phase within some $\mathrm{Al}_{12} \mathrm{Mg}_{17}$ compounds, as shown in Fig. 6. EDS microanalysis indicated that the secondary phase has a composition similar to that of $\alpha-\mathrm{Mg}$. Consequently, the mixture of $\alpha-\mathrm{Mg}$ and $\beta$ $\mathrm{Al}_{12} \mathrm{Mg}_{17}$ at the grain boundaries could be considered as an eutectic structure. According to the Al-Mg binary phase diagram,${ }^{10)}$ the eutectic point exists at the composition of 


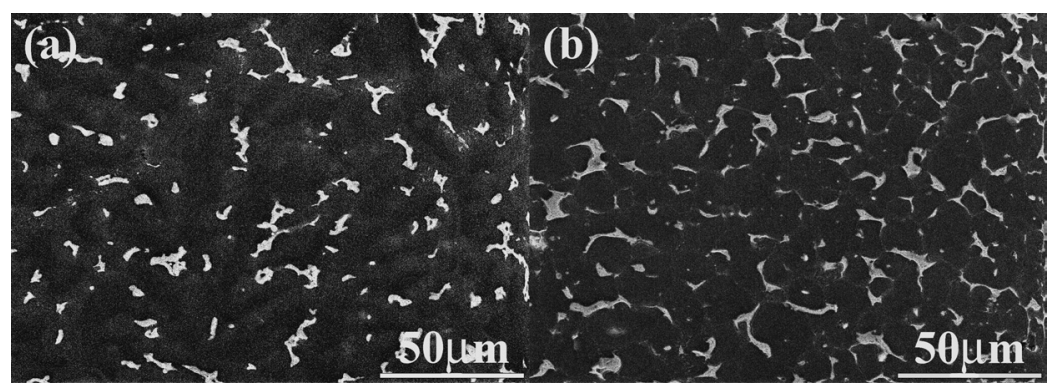

Fig. 5. Microstructures of magnesium alloy weld metals deposited by wire B and wire A at welding input of $110.4 \mathrm{~kJ}$. (a) Weld metal with $6.9 \mathrm{wt} \%$ Al. (b) Weld metal with $9.8 \mathrm{wt} \% \mathrm{Al}$.

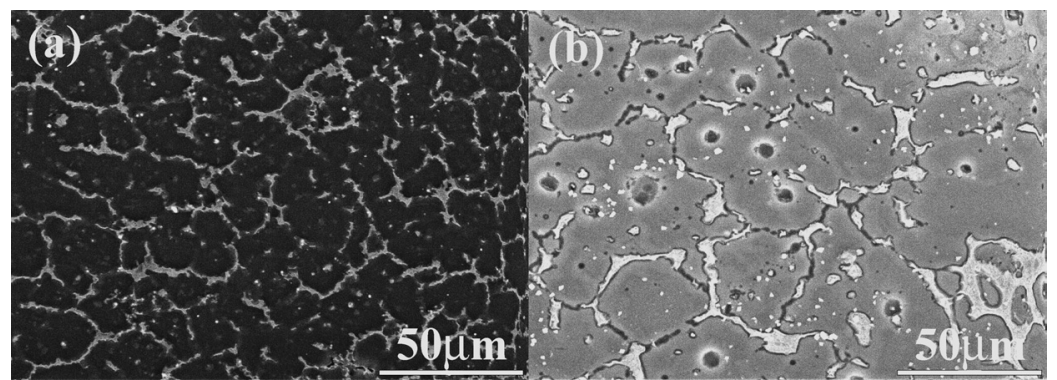

Fig. 7. Microstructures of weld metals deposited at heat inputs of $73.6 \mathrm{~kJ}$ and $147.2 \mathrm{~kJ}$ with the wire A. (a) $73.6 \mathrm{~kJ}$, (b) $147.2 \mathrm{~kJ}$.

$32.3 \mathrm{wt} \% \mathrm{Al}$ and the temperature of $437^{\circ} \mathrm{C}$, the maximum solubility of $\mathrm{Al}$ in $\alpha-\mathrm{Mg}$ is $12.7 \mathrm{wt} \%$ at $437^{\circ} \mathrm{C}$, and the solidification sequence does not allow an eutectic structure in magnesium alloys containing $6.9 \mathrm{wt} \% \mathrm{Al}$ and $9.8 \mathrm{wt} \% \mathrm{Al}$. However, the solidification rate of weld molten pool is very fast and there is little diffusion in the solid. During the solidification of the magnesium alloy welding molten pool, the first $\alpha-\mathrm{Mg}$ grain to form was purer than the liquid from which it formed and the solute (Al) had to be rejected into the liquid, raising its concentration. With further solidification, the liquid between $\alpha$-Mg grains became progressively richer in $\mathrm{Al}$ and may even attain the eutectic composition at the eutectic temperature due to rapid solidification and little diffusion in $\alpha-\mathrm{Mg}$. The solidification characterization of the welding molten pool results in the formation of the eutectic structure consisting of $\alpha-\mathrm{Mg}$ and $\beta-\mathrm{Al}_{12} \mathrm{Mg}_{17}$ in the weld metals and the segregation of $\beta-\mathrm{Al}_{12} \mathrm{Mg}_{17}$ at the grain boundaries. The higher weld $\mathrm{Al}$ contents tend to cause more $\mathrm{Al}$ segregation to grain boundaries and promote to form more $\beta-\mathrm{Al}_{12} \mathrm{Mg}_{17}$ in the weld metal. It is the main reason that the area fraction of $\beta-\mathrm{Al}_{12} \mathrm{Mg}_{17}$ in the weld metal increases with increasing weld $\mathrm{Al}$ content.

Figure 7 shows microstructures of weld metals deposited at different heat inputs by using welding wire A. XRD analysis and SEM examination indicated that the heat input does not change the phase composition $(\alpha-\mathrm{Mg}$ and $\beta$ $\left.\mathrm{Al}_{12} \mathrm{Mg}_{17}\right)$ of the weld metals, but it has the effect on grain size of weld metals. With an increase of the heat inputs from 73.6 to $147.2 \mathrm{~kJ}$, the grain coarsening in the weld metals was observed. It can be explained by the welding molten pool keeping long time at high temperature and experiencing slow cooling rate under the condition of the increased heat input. In addition, the change of dilution ratio due to the change in heat input had also the effect on the composition of the weld metal. With increasing the heat input from

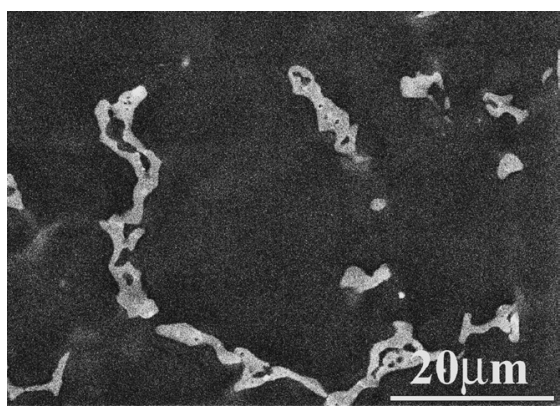

Fig. 6. Morphology of $\beta-\mathrm{Al}_{12} \mathrm{Mg}_{17}$ at grain boundaries.

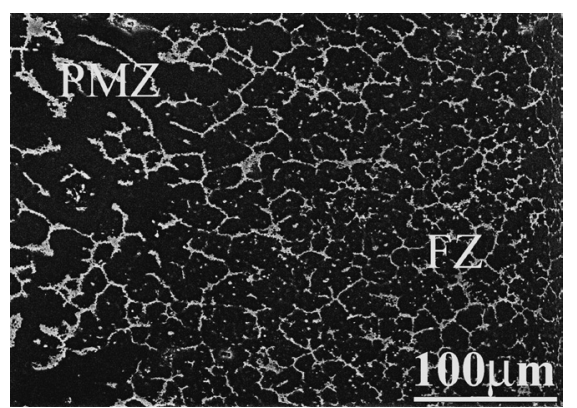

Fig. 8. Microstructure of $P M Z$ in the joint obtained at heat input of $110.4 \mathrm{~kJ}$ with the wire A.
73.6 to $147.2 \mathrm{~kJ}$, the dilution ratio increased from 25.3 to $38.7 \%$. When the welding wire A was used as filler metal, the dilution ratio had little effect on the weld composition, because it had the same composition as the base metal (AZ91D). When the welding wire B was used, the weld Al content increased from 6.6 to $7.3 \mathrm{wt} \%$ with increasing the dilution ratio from 25.3 to $38.7 \%$, and the amount of $\beta$ $\mathrm{Al}_{12} \mathrm{Mg}_{17}$ in the weld metal had an increased tendency.

In the HAZ, the partially melted zone (PMZ) immediately adjacent to the fusion line is very small in the width $(100-250 \mu \mathrm{m})$ and exhibits an obvious change in microstructure. In the $\mathrm{PMZ}$, the $\beta-\mathrm{Al}_{12} \mathrm{Mg}_{17}$ at the grain boundaries is broader than that in the base metal, as shown in Fig. 8. During welding, the temperature of the base metal immediately adjacent to the welding molten pool rose above the melting temperature of grain boundary precipitations $\left(\beta-\mathrm{Al}_{12} \mathrm{Mg}_{17}\right)$ and liquid layers were created along the grain boundaries. The liquid layers might dissolve some of the surrounding $\mathrm{Mg}$ matrix. Therefore, upon resolidification of these liquid layers, the broader $\beta-\mathrm{Al}_{12} \mathrm{Mg}_{17}$ was formed at the grain boundaries. With an increase of the heat inputs from 73.6 to $147.2 \mathrm{~kJ}$, the PMZ width increased from 120 to $210 \mu \mathrm{m}$. It is related to enlarging the dimension, in which the temperature of base metal immediately adjacent to the welding molten pool rises above the melting temperature of grain boundary precipitations.

\subsection{Mechanical Properties of Joints}

Mechanical properties of magnesium alloy base metal, weld metals and welded joints are summarized in Table 2. The variation ranges of tensile strength and elongation of the base metal are in $139-161 \mathrm{MPa}$ and $4.2-5.1 \%$ respectively, the average tensile strength and elongation being $156 \mathrm{MPa}$ and $4.8 \%$, respectively. The weld metal with composition $(9.8 \mathrm{wt} \% \mathrm{Al})$ similar to that of the base metal has 
Table 2. Mechanical properties of base metal, weld metal and welded joint.

\begin{tabular}{ccc}
\hline Weld and joint & Strength(MPa) & Elongation(\%) \\
\hline Base metal AZ91D & 156 & 4.8 \\
Weld metal (6.9wt\%Al) & 215 & 7.9 \\
Weld metal (9.8wt\%Al) & 192 & 4.9 \\
Joint with weld (6.9wt\%Al) & 115 & 3.5 \\
Joint with weld (9.8wt\%Al) & 107 & 3.5 \\
\hline
\end{tabular}

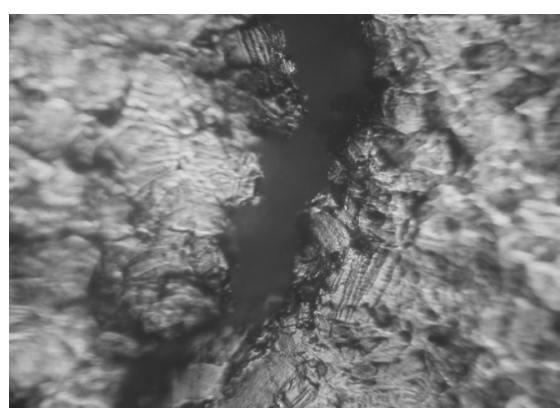

Fig. 9. Fracture morphology of weld tensile test specimen crosssection $(6.9 \mathrm{wt} \% \mathrm{Al})$ with wire $\mathrm{B}$.

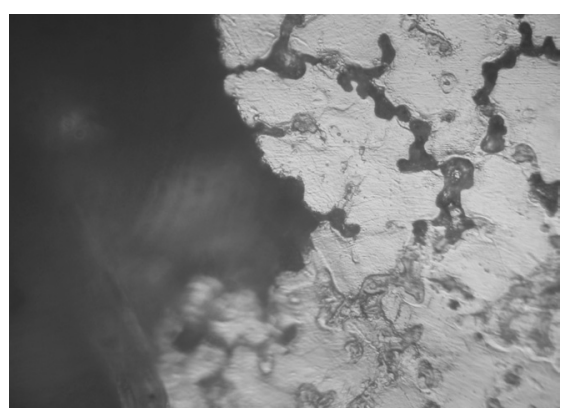

Fig. 10. Fracture morphology of weld tensile test specimen cross-section $(9.8 \mathrm{wt} \% \mathrm{Al})$ with wire $\mathrm{A}$.

superior mechanical properties compared with the base metal. The weld strength of $192 \mathrm{MPa}$ is approximately $23 \%$ higher than that of the base metal. It can be explained by the weld grain refinement due to the relatively high cooling rate. The experimental results showed that the weld Al contents have obvious effects on the mechanical properties of weld metals. Increasing the $\mathrm{Al}$ contents from 6.9 to $9.8 \mathrm{wt} \%$, the strength and elongation of the weld metals decreased from $215 \mathrm{MPa}$ and $7.9 \%$ to $192 \mathrm{MPa}$ and $4.9 \%$. The strength and elongation decreased by $11 \%$ and $40 \%$, respectively. From fracture morphologies of weld tensile test specimen cross-sections shown in Figs. 9 and 10, it can be seen that fractures in both weld metals with $6.9 \mathrm{wt} \% \mathrm{Al}$ and $9.8 \mathrm{wt} \% \mathrm{Al}$ always propagated along the grain boundaries with $\mathrm{Al}_{12} \mathrm{Mg}_{17}$ phases. For the weld tensile specimen with $6.9 \mathrm{wt} \% \mathrm{Al}$, some slip bands corresponding to the motion of large numbers of dislocations and tear dimples were observed on the fracture cross-section and fracture surface (Fig. 9 and Fig. 11). It means that plastic deformation occurred in the vicinity of an advancing fracture. On the other hand, for the weld tensile specimen with $9.8 \mathrm{wt} \% \mathrm{Al}$, there was not appreciable plastic deformation (Fig. 10) and the fracture surface morphology displayed a typical intergranular fracture feature in which the three-dimensional nature of grains could be seen on the fracture surface of the tensile specimen, as shown in Fig. 12.

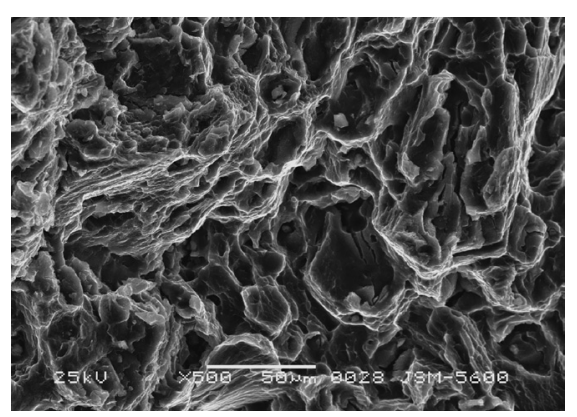

Fig. 11. Fracture surface morphology of weld tensile test specimen $(6.9 \mathrm{wt} \% \mathrm{Al})$ with wire B.

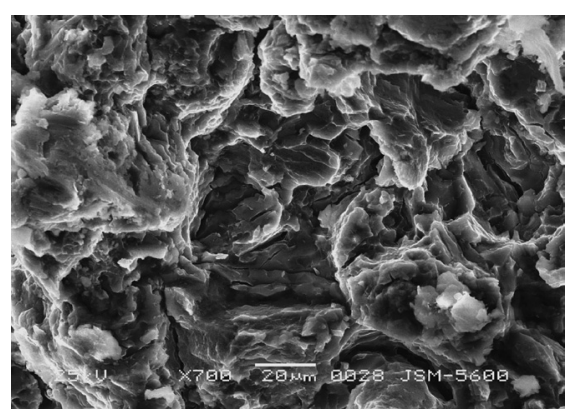

Fig. 12. Fracture surface morphology of weld tensile test specimen $(9.8 \mathrm{wt} \% \mathrm{Al})$ with wire A.

The magnesium alloy weld metals consist of $\alpha-\mathrm{Mg}$ and $\beta-\mathrm{Al}_{12} \mathrm{Mg}_{17}$ at grain boundaries. Due to the brittleness of the $\mathrm{Al}_{12} \mathrm{Mg}_{17}$ phase, effects of $\mathrm{Al}$ contents on mechanical properties of the weld metals are related to the area fraction of $\beta-\mathrm{Al}_{12} \mathrm{Mg}_{17}$ at grain boundaries. The increased weld $\mathrm{Al}$ content caused more $\mathrm{Al}$ segregation to grain boundaries during welding molten pool solidification and increased the area fraction of brittle $\mathrm{Al}_{12} \mathrm{Mg}_{17}$ phases in the weld metal. This is the main reason that the weld metal with $6.9 \mathrm{wt} \% \mathrm{Al}$ has superior mechanical properties than the weld metal with $9.8 \mathrm{wt} \% \mathrm{Al}$. Therefore, it is important to select appropriate weld composition for improving the mechanical properties of magnesium alloy weld metals.

From Table 2, it can be seen that the mechanical properties of welded joints are poor compared with those of the base metal. The strength and elongation of the joints are about $70 \%$ and $73 \%$ of those of the base metal, respectively. The joint fractures occurred in HAZ, especially in PMZ immediately adjacent to the fusion line. Figure 13 shows a typical fracture morphology of tensile specimen cross-section corresponding to fracture propagation along grain boundaries with the brittle $\mathrm{Al}_{12} \mathrm{Mg}_{17}$ phases in PMZ. The decreased joint properties are mainly associated with the broader $\mathrm{Al}_{12} \mathrm{Mg}_{17}$ phase precipitating along the grain boundaries in PMZ. Therefore, it is favorable to decrease the heat input of welding for improving the mechanical 


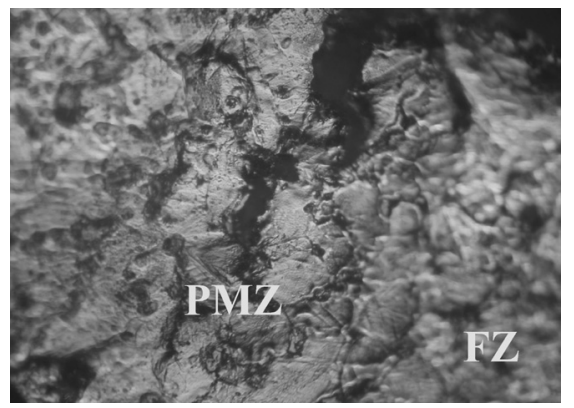

Fig. 13. Fracture morphology in PMZ of welded joint with wire A.

properties of the welded joints.

\section{Conclusions}

(1) Magnesium alloy weld metals consist of $\alpha-\mathrm{Mg}$ and $\beta-\mathrm{Al}_{12} \mathrm{Mg}_{17}$ at the grain boundaries. The weld microstructures mainly depend on the chemical composition and the heat input of welding. Increasing weld $\mathrm{Al}$ contents from 6.9 to $9.8 \mathrm{wt} \%$, the area fraction of $\beta-\mathrm{Al}_{12} \mathrm{Mg}_{17}$ in the weld metals increases from 6.2 to $7.3 \%$. Increasing the heat input results in the grain coarsening of the weld metals.

(2) In the HAZ of TIG welded AZ91D, the PMZ immediately adjacent to the fusion line is very small in the width $(100-250 \mu \mathrm{m})$ and the $\beta-\mathrm{Al}_{12} \mathrm{Mg}_{17}$ at the grain boundaries is broader than that in the base metal. With an increase of the heat input from 73.6 to $147.2 \mathrm{~kJ}$, the PMZ width increases from 120 to $210 \mu \mathrm{m}$.

(3) Weld Al contents have obvious effects on mechanical properties of the weld metals. Increasing $\mathrm{Al}$ contents from 6.9 to $9.8 \mathrm{wt} \%$, the strength and elongation of the weld metals decrease from $215 \mathrm{MPa}$ and $7.9 \%$ to $192 \mathrm{MPa}$ and $4.9 \%$, the strength and elongation decreasing by $11 \%$ and $40 \%$, respectively. It is mainly attributed to the increased area fraction of brittle $\mathrm{Al}_{12} \mathrm{Mg}_{17}$ phases in the weld metal.

(4) The mechanical properties of welded joints are poor compared with those of the base metal. The strength and elongation of the joints are about $70 \%$ and $73 \%$ of those of the base metal, respectively. The joint fractures mainly occur in PMZ with the broader $\mathrm{Al}_{12} \mathrm{Mg}_{17}$ phases at the grain boundaries.

\section{Acknowledgement}

The authors would like Ministry of Education of China for financial support. They would also like to thank Professor H. Zhou in the school of Materials Science and Engineering of Jilin University (Changchun, China) for providing the magnesium alloy materials.

\section{REFERENCES}

1) E. Rober: Light Met. Age, 6 (2001), 54.

2) S. Lee, S. H. Lee and D. H. Kim: Metall. Mater. Trans. A, 29A (1998), 1221.

3) D. Thomas: Automot. Eng., 99 (1991), 47.

4) A. Weisheit, R. Galun and B. L. Mordike: Weld. Res. Suppl., 77 (1998), 149.

5) S. F. Su, J. C. Huang, H. K. Lin and N. J. Ho: Metall. Mater. Trans. $A, 33$ A (2002), 1461.

6) M. Marya, G. R. Edwards and S. Liu: Weld. J., 7 (2004), 203.

7) S. H. C. Park, Y. S. Stad and H. Kokawa: J. Mater. Sci., 38 (2003), 4379.

8) D. Q. Sun, W. H. Liu and X. Y. Gu: Mater. Sci. Technol., 20 (2004), 1595.

9) A. Munitz, C. Cotler, A. Stem and G. Kohn: Mater. Sci. Eng. A, 302, (2001), 68 .

10) T. B. Massalski, J. L. Murray, L. H. Bennett and H. Baker: Binary Alloy Diagrams, ASM International, Materials Park, Ohio, (1986), 129. 